\title{
Targeting the Glutamatergic System for the Treatment of HIV-Associated Neurocognitive Disorders
}

\author{
Michelle C. Potter • Mariana Figuera-Losada • \\ Camilo Rojas • Barbara S. Slusher
}

Received: 7 February 2013 / Accepted: 8 February 2013 / Published online: 4 April 2013

(C) The Author(s) 2013. This article is published with open access at Springerlink.com

\begin{abstract}
The accumulation of excess glutamate in the extracellular space as a consequence of CNS trauma, neurodegenerative diseases, infection, or deregulation of glutamate clearance results in neuronal damage by excessive excitatory neurotransmission. Glutamate excitotoxicity is thought to be one of several mechanisms by which HIV exerts neurotoxicity that culminates in HIV-associated neurocognitive disorders (HAND). Excess glutamate is released upon HIV infection of macrophage/microglial cells and has been associated with neurotoxicity mediated by gp120, transactivator of transcription (Tat) and other HIV proteins. Several strategies have been used over the years to try to prevent glutamate excitotoxicity. Since the main toxic effects of excess glutamate are thought to be due to excitotoxicity from over activation of glutamate receptors, antagonists of these receptors have been popular therapeutic targets. Early work to ameliorate the effects of excess
\end{abstract}

Michelle C. Potter and Mariana Figuera-Losada contributed equally.

M. C. Potter · M. Figuera-Losada · C. Rojas · B. S. Slusher Brain Science Institute NeuroTranslational Drug Discovery Program, Johns Hopkins University School of Medicine, Baltimore, MD, USA

M. C. Potter $\cdot$ M. Figuera-Losada $\cdot$ B. S. Slusher Department of Neurology, Johns Hopkins University School of Medicine, Baltimore, MD, USA

B. S. Slusher

Department of Psychiatry,

Johns Hopkins University School of Medicine, Baltimore, MD, USA

B. S. Slusher $(\bowtie)$

Brain Science Institute, Johns Hopkins University School of Medicine, 855 North Wolfe Street,

Baltimore, MD 21205, USA

e-mail: bslusher@jhmi.edu extracellular glutamate focused on NMDA receptor antagonism, but unfortunately, potent blockade of this receptor has been fraught with side effects. One alternative to direct receptor blockade has been the inhibition of enzymes responsible for the production of glutamate such as glutaminase and glutamate carboxypeptidase II. Another approach has been to regulate the transporters responsible for modulation of extracellular glutamate such as excitatory amino acid transporters and the glutamate-cystine antiporter. There is preliminary experimental evidence that these approaches have potential therapeutic utility for the treatment of HAND. These efforts however, are at an early stage where the next steps are dependent on the identification of drug-like inhibitors as well as the development of predictive neuroAIDS animal models.

Keywords Glutamate $\cdot$ HIV-associated neurocognitive disorder · Excitotoxicity · Glutaminase · Glutamate carboxypeptidase II

\section{Introduction}

The introduction of combination antiretroviral therapy (cART) in 1996 brought a dramatic reduction in HIV RNA levels and thus morbidity and mortality rates in human immunodeficiency virus (HIV) infected individuals (Coiras et al. 2009). Although cART has been successful, it has not eradicated the disease as the virus can persist in resting memory $\mathrm{CD}^{+} \mathrm{T}$ cells as well as macrophages and astrocytes (Coiras et al. 2009). These latent reservoirs of HIV are easily and quickly activated if cessation of cART treatment occurs (Lewin et al. 2008). Elimination of these reservoirs is a major goal of current research in the HIV field. Even with 
continuous cART therapy, significant morbidity persists, in particular in the central nervous system (CNS) (Gorantla et al. 2012) where memory problems and dementia are common. It is thought that HIV-associated neurocognitive disorders (HAND) remain high due to both latent reservoir and reduced penetrance of cART to the brain.

HIV initially enters the brain by crossing the blood brain barrier via monocytes and lymphocytes very shortly after infection (Fig. 1). The virus then takes up permanent brain residence mainly in microglia, macrophages and astrocytes (Kaul et al. 2001; Tan and McArthur 2012). HIV does not infect neurons, though neural progenitor cells appear able to take up the virus (Kaul 2008). Neurotoxicity in patients with HIV-1 infection is thought to be mediated by HIV-1 proteins such as gp120 and transactivator of transcription (Tat), as well as other products released from infected cells. The mechanisms of neurotoxicity are thought to be both direct and indirect including glutamate excitotoxicity, oxidative stress, increase in apoptosis, altered calcium homeostasis, stimulation of tumor necrosis factor-alpha $(\mathrm{TNF}-\alpha)$ and nuclear factor $\mathrm{kB}(\mathrm{NF}-\mathrm{kB})$ and stimulation of nitric oxide production. These mechanisms are likely acting in concert.

Although multiple mechanisms are at play, the objective of this review is to present the evidence which indicates that glutamate excitotoxicity is a factor in HIV neurotoxicity and to focus on how this evidence suggests potential opportunities to ameliorate HAND through pharmacological manipulations of the glutamate system.

\section{Mechanisms of glutamate excitotoxicity in HAND}

The amino acid glutamate is the principal excitatory neurotransmitter in mammalian CNS where it is synthesized and stored in the neuronal cytosol in synaptic vesicles in millimolar concentrations (Nedergaard et al. 2002). Extracellular concentrations of glutamate in the synaptic cleft are kept low (nanomolar ranges) by excitatory amino acid transporters (EAATs). These are glutamate transporters which are located mainly on astrocytes and function in removing excess glutamate from the synaptic cleft after the completion of a signaling event, returning it to homeostatic levels.

The accumulation of excess glutamate in the extracellular space as a consequence of CNS trauma, neurodegenerative diseases, infection, or deregulation of glutamate clearance results in excitotoxicity. The presence of excess glutamate in the synaptic clefts activates glutamate gated ion channels and results in high levels of ion influx into neuronal cells allowing the over activation of downstream calcium iondependent effectors and signaling pathways, culminating in neuronal damage. Neuronal damage then causes further release of intracellular glutamate into the extracellular space affecting nearby neurons. Most acute and chronic neuronal diseases, including HAND, have implicated this type of bystander pathology of excitotoxicity.

HIV infection of macrophages and microglial cells causes excess glutamate release and impaired uptake

Macrophages and microglia, the resident macrophages in the CNS, are key cellular components of innate immunity. These cells can release a diversity of trophic factors and cytokines that control the behavior and/or destiny of other cells by promoting cell proliferation, migration, recruitment, and apoptosis. Additionally, macrophages and microglial cells play an important role in the phagocytosis of invading pathogens, tissue repair and the clearance of debris (Liu and Hong 2003). The activity of these cells is highly regulated both spatially and temporally due to the potential deleterious effects of their uncontrolled hyperactivation, which include increase in inflammation and cell death. Microglial cells are particularly susceptible to alterations in their surroundings, becoming easily activated, changing morphology and up-regulating the production of a number of membrane receptors and soluble factors (Kreutzberg 1996; Ransohoff and Perry 2009). Conditions that involve neuronal degeneration like HAND, Alzheimer's disease, cerebral ischemia and multiple sclerosis, have been associated with microglial cells pathological activity (Gao and Hong 2008; Zindler and Zipp 2010).

Invasion of the brain seems to occur very early in the progression of the disease. However, there is no convincing evidence of HIV-1 neuronal infection despite the fact that HIV-1 associated neuronal dysfunction is accompanied by substantial neuronal loss in the neocortex, putamen, globus pallidus, substantia nigra and hippocampus (Everall et al. 1991; Masliah et al. 1992). Hence it is widely accepted that macrophages and microglial cells are responsible for producing and releasing the neurotoxic factors that cause neuronal death (Gendelman 2012). HIV-1 is capable of infecting $\mathrm{CD}^{+}$macrophages and T-cells (Chen et al. 1983; Popovic et al. 1983; Klatzmann et al. 1984a, b). Infected macrophages are thought to cross the blood-brain barrier (BBB), turn into resident CNS macrophages and mediate the spread of the virus in the brain (Fig. 1). There is considerable evidence that supports this hypothesis ("Trojan horse" hypothesis) as the mechanism of brain infection by HIV-1 (Peluso et al. 1985; Budka 1986, 1991; Koenig et al. 1986; Kure et al. 1990; Dickson et al. 1993; Fischer-Smith et al. 2001). Upon activation, HIV-1 infected macrophages and microglial cells release chemokines, inflammatory cytokines (TNF- $\alpha$, IL-1 $\beta$, IL- 


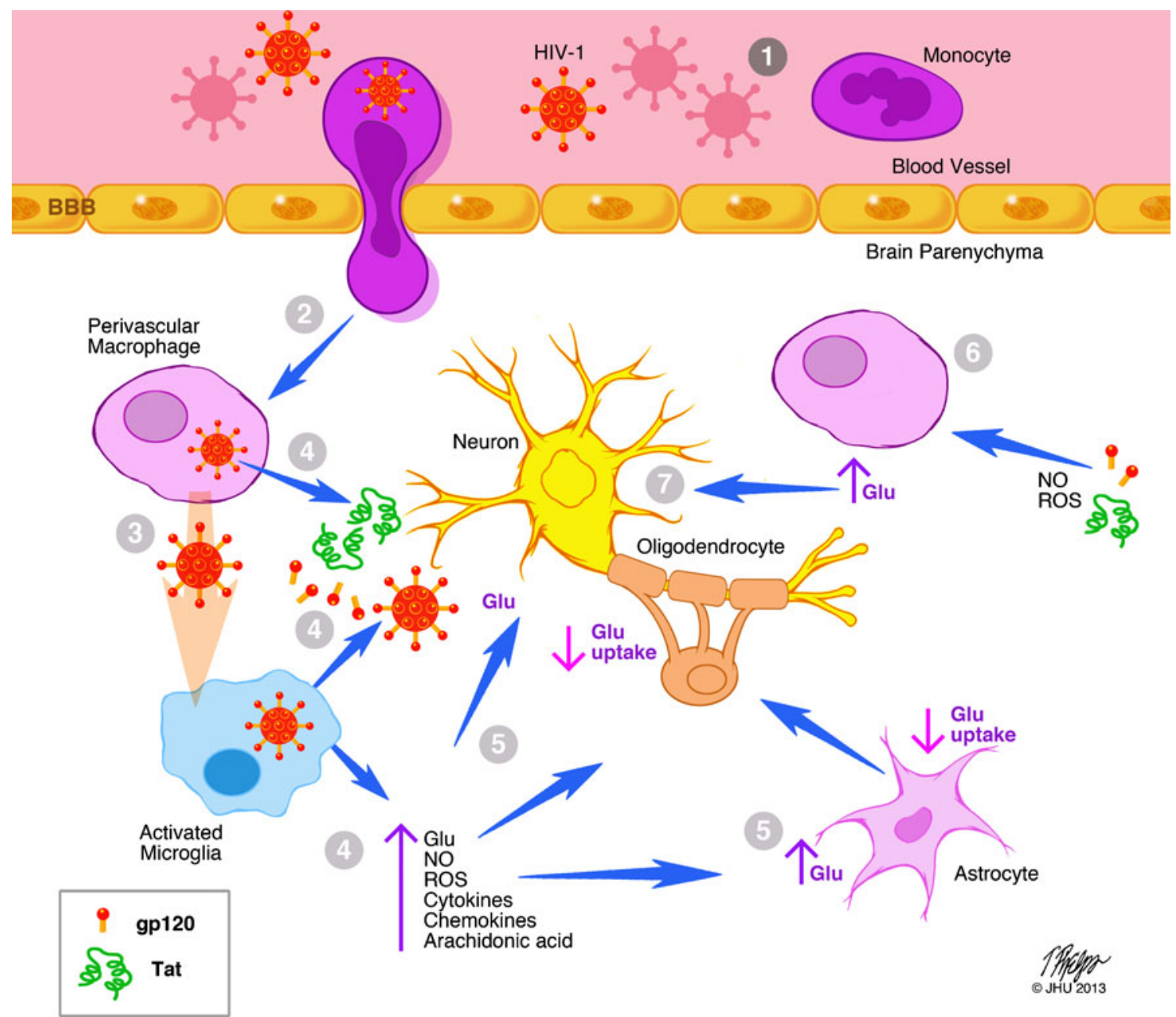

Fig. 1 Mechanisms of glutamate excitoxicity during HIV-1 infection (1) Infection of circulating monocytes with HIV-1. (2) HIV-1 infected macrophages cross the BBB and become perivascular macrophages. (3) HIV-1 infected perivascular macrophages in the brain parenchyma release viral particles that infect other brain macrophages and microglial cells. (4) Activated macrophages and microglial cells release viral proteins gp120 and Tat, glutamate and other factors such as NO, ROS, cytokines, chemokines and arachidonic acid that can either directly or indirectly affect glutamate metabolism and/or transport. (5) Decrease in glutamate uptake by oligodendrocytes and astrocytes

6), nitric oxide (NO) and glutamate. Excess glutamate can induce neuronal damage through N-methyl-D-aspartate (NMDA) receptor activation (Cutler and Dudzinski 1974; Fonnum 1984). Indeed, HIV-1 infected patients show elevated CSF glutamate levels that correlate with the severity of the dementia and the degree of brain atrophy (Ferrarese et al. 2001).

Several glutamate targets (Fig. 2) have been shown to be affected by HIV infection. HIV-1 infected human macrophages and human primary fetal microglia cells have increased glutaminase mRNA and protein levels resulting in elevated extracellular glutamate levels that due to increased levels of these toxins released by HIV-1 infected macrophages and microglial cells. These factors also cause an increase in vesicular glutamate release by astrocytes. (6) Viral proteins Tat and gp120 and oxidative stress induced by ROS and NO cause an increase in the activity of $\mathrm{xCT}$ in uninfected perivascular macrophages and microglia and as a consequence extracellular levels of glutamate increase. (7) Excessive extracellular glutamate triggers activation of glutamate receptors on neurons causing an increase in the intracellular calcium levels, cell death and neuronal degeneration

cause reduced viability of cortical neurons in co-culture or of neurons incubated with conditioned media from these infected cells (Tian et al. 2008; Erdmann et al. 2009; Huang et al. 2011; Zhao et al. 2012). MK-801 (dizocilpine) a non-competitive antagonist at the NMDA receptor abolished the effects on neuronal viability, suggesting this is an NMDA receptor-dependent process (Wong et al. 1986).

Treatment of macrophages and microglial cells with proinflammatory factors like lipopolysaccharides (LPS) or HIV-1 Tat protein generates reactive oxygen species (ROS), which seem to contribute to the accumulation of 


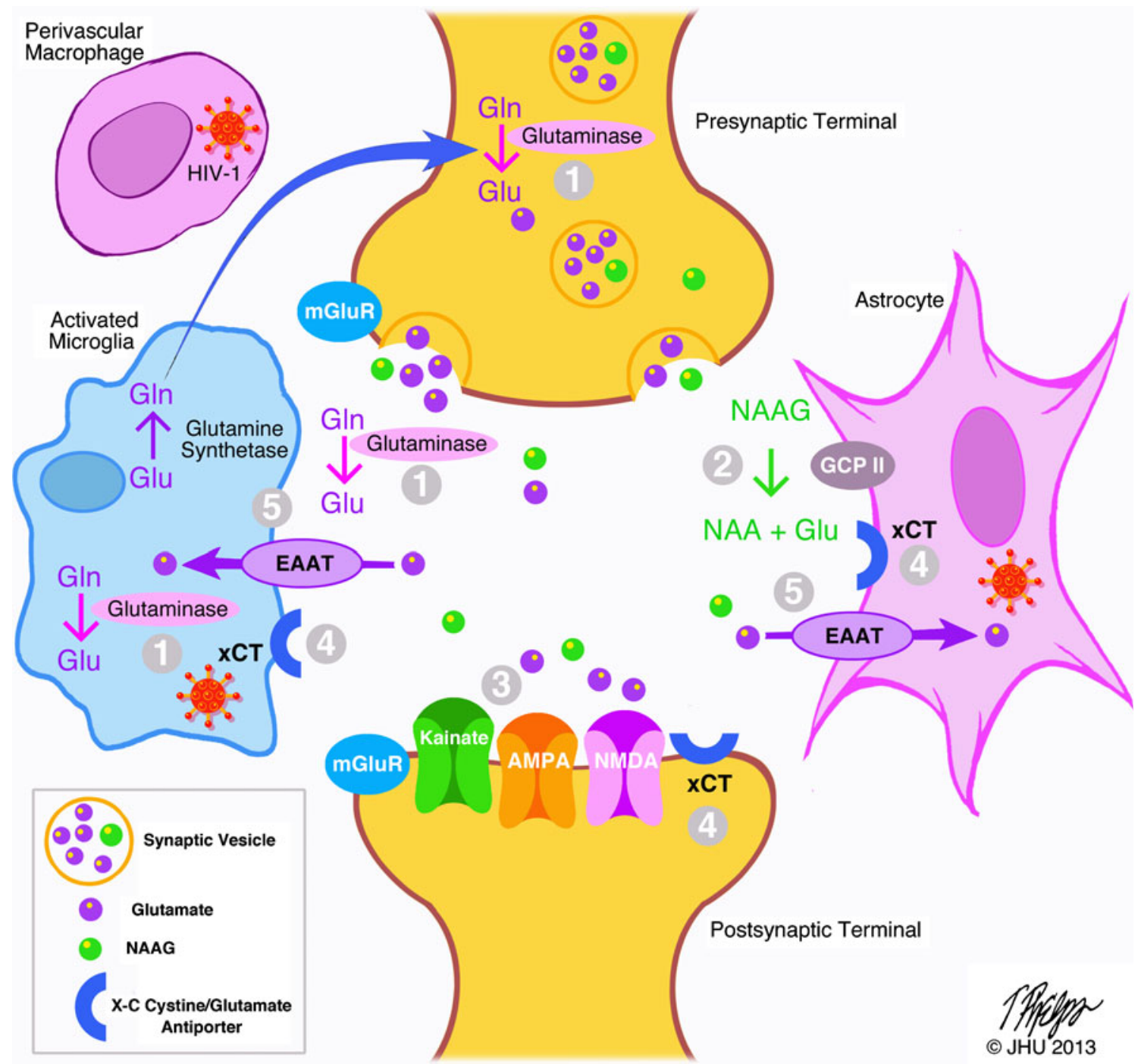

Fig. 2 Potential ways to regulate glutamate excitotoxicity for the treatment of HAND (1) Inhibition of glutaminase - glutaminase is a neuronal enzyme that produces glutamate by the deamination of glutamine. During HIV-1 infection, it is increased in glial cells and the synaptic cleft. (2) Inhibition of GCPII - GCPII is an astrocytic enzyme that catalyzes the hydrolysis of NAAG to N-acetyl aspartate (NAA) and glutamate. (3) Blockade of glutamate receptors- glutamate receptors such as NMDA, AMPA, kainate and mGluR are targets for

extracellular glutamate and neuronal cell death in a process involving the glutamate-cystine antiporter (xCT) (Barger et al. 2007; Niki 2009).

It has been shown that up to $19 \%$ of astrocytes in the brain of patients with HAND are infected with HIV-1 and that there is a direct correlation between the level of infected astrocytes and the degree of neuropathological changes (Churchill et al. 2009). Unlike macrophages and microglia, astrocytes are latently infected by HIV-1 making these cells incapable of releasing viral particles. Nonetheless, HIV-1 mRNAs (Tat, Rev and Ref) and proteins (Nef) accumulate inside astrocytes affecting their function (Sabri et al. 2003). inhibition of glutamate excitotoxicity in HAND. (4) Inhibition of $\mathrm{xCT}-\mathrm{xCT}$ transports extracellular cys 2 into cells and intracellular glutamate into the extracellular space. (5) Activation of glutamate transporters (e.g. EAAT1) - glutamate transporters mobilize glutamate away from the synaptic cleft. Glutamate and NAAG are released through intracellular vesicles at the presynaptic terminal during neurotransmission. The illustration shows NAAG and glutamate in the same vesicles but it is not known if they are in the same or different vesicles

Changes induced in astrocytes by HIV infection include activation, production and release of inflammatory cytokines and chemokines, and glutamate release (Fig. 1) (Benveniste 1998; Bajetto et al. 2002; John et al. 2003; Eugenin and Berman 2007; Farina et al. 2007).

Cytokines such as TNF- $\alpha$ and IL- $1 \beta$ released by activated microglia, macrophages or astrocytes treated with viral proteins like gp120 or Tat cause increased glutamate release and decreased extracellular glutamate uptake by astrocytes due to down regulation of EAAT1 and EAAT2 gene expression (Wang et al. 2004; Lee et al. 2005; Brabers and Nottet 2006; Cheung et al. 2008). 
Moreover, excess extracellular glutamate can induce elevation of intracellular calcium levels in astrocytes which in turn increases even more the release of glutamate from those cells in an autocrine manner (Verderio et al. 2001; Verderio and Matteoli 2001). Calcium influx in astrocytes may decrease EAAT1 levels in these cells by a CD38-dependent mechanism contributing to the accumulation of extracellular glutamate (Bruzzone et al. 2004; Liu et al. 2010). In short, a major contributor to the neuronal toxicity due to glutamate in HAND seems to be the aberrant glutamate transport and/or metabolism in astrocytes caused by viral toxins, cytokines or glutamate.

Glutamate toxicity in HIV-1 infected patients could also depend on altered glutamate transport in oligodendrocytes (Domercq et al. 2007). Co-culture of LPS-activated microglia and oligodendrocytes or incubation of oligodendrocytes with conditioned media from LPS-activated microglia inhibited glutamate uptake by oligodendrocytes resulting in extracellular glutamate accumulation and cell death (Pang et al. 2010). Moreover, peroxynitrite, the product of the reaction between superoxide and NO, is a potent inhibitor of EAAT glutamate transporters GLAST, GLT-1 and EAAC1 (Trotti et al. 1996). Taken together, compromised clearance of extracellular glutamate from the synaptic cleft by oligondendrocytes, allows levels of glutamate to increase and cause toxicity in neurons.

\section{GP120 neurotoxicity and glutamate}

Gp120 is the main HIV envelope glycoprotein that, along with gp41, allows the entry of HIV-1 into cells via the CD4 receptor along with CCR5 and CXCR4 receptors. The amino acid sequence of this protein consists of five variable regions (V1-V5) and five constant domains (C1-C5) (Checkley et al. 2011). There is both in vitro and in vivo evidence indicating that gp120 triggers neurotoxicity (Doble 1999). Gp120 is toxic to cultured rat hippocampal neurons in vitro (Brenneman et al. 1988; Dreyer and Lipton 1995), produces cognitive deficits in rats (Glowa et al. 1992) and causes impaired neuronal development in rat neonates (Hill et al. 1993; Bagetta et al. 1994). Further, transgenic mice expressing gp120 in astrocytes develop neurodegeneration (Toggas et al. 1994). Gp120 neurotoxicity is thought to contribute to cortical atrophy (Lipton 1992a), a condition associated with cognitive impairment observed in some AIDS patients (Power and Johnson 1995).

NMDA receptor antagonists, but not CNQX, an AMPA receptor antagonist, prevent in vitro gp120 neurotoxicity in rodent cultures suggesting that gp120 neurotoxicity is mediated, at least in part, by the NMDA receptor (Lipton et al. 1991; Lipton 1992a, b; Muller et al. 1992; Savio and Levi 1993). Interestingly, if glutamate is removed enzymatically from the cell culture milieu, gp120 excitotoxicity is lost (Lipton et al. 1991). Furthermore, neurodegeneration in gp120-expressing transgenic mice can be ameliorated by the NMDA antagonist memantine (Toggas et al. 1996) and the glutamate release inhibitor riluzole (Sindou et al. 1994).

Gp120 is also known to trigger NMDA receptormediated cell death in human neurons (Corasaniti et al. 1995; Lannuzel et al. 1995; Wu et al. 1996). However, gp120 receptors (CD4 receptors) are not found in neurons so that gp120 neurotoxicity mediated by NMDA receptors is likely through an indirect mechanism (Lipton et al. 1991) involving glutamate release from infected macrophage and microglia. Macrophages are essential in order to see the neurotoxic effect of gp120 (Lipton 1992c). Unlike neurons, macrophages express CD4 receptors that recognize gp120. In addition, stimulation of macrophages with gp120 releases arachidonic acid which impairs glutamate uptake by astrocytes (Dreyer and Lipton 1995) thus providing an explanation for the build-up of glutamate in the synapse.

Tat neurotoxicity and glutamate

HIV-1 Tat is a small basic protein (86-101 residues, depending on the viral isolate) encoded by the HIV-1 genome that plays an important role enhancing the efficiency of transcription from viral dsDNA (Debaisieux et al. 2012). Tat protein is encoded by two exons, the first one corresponds to the $72 \mathrm{~N}$-terminal residues and the second one the remaining 14-32 residues (Cheng et al. 1998).

In addition to its role in viral replication, this protein is secreted from intact HIV-1 infected cells at nanomolar levels and is found in serum, CSF and brain of HIV-1 infectedpatients (Xiao et al. 2000). Fragments of Tat have been shown to cause apoptosis in human peripheral blood mononuclear cells, T-cells, neuroblastoma, rat cortical neurons and human fetal primary neuronal cells (New et al. 1998). Moreover, injection of HIV-1 Tat in mice caused neurotoxicity, seizures, death, neuronal degeneration, astrocytosis and microglia activation (Sabatier et al. 1991; Philippon et al. 1994).

Tat peptides were shown to be neuroexcitatory and neurotoxic in cultured human fetal neurons triggering the release of calcium ion from intracellular stores (Haughey et al. 1999, 2001; Holden et al. 1999). This calcium release causes membrane depolarization, activation of metabolic pathways, ROS generation and apoptosis (Nath et al. 1996; Kaul et al. 2001). Release of Tat-mediated calcium ion seems dependent on NMDA receptor activation since NMDA receptor antagonists MK-801 and D-2-amino-5phosphonovalerate (AP-5), significantly decrease cell death induced in neurons and astrocytes by Tat (Eugenin et al. 2007). It is thought that Tat causes the release of $\mathrm{Zn}^{2+}$ from its binding site on the NMDA receptor, causing activation 
and increasing its capacity to allow calcium ion influx (Chandra et al. 2005). Tat can bind to lipoprotein related protein (LRP) receptor and form a complex with postsynaptic density protein-95 (PSD-95), NMDA receptor and neuronal nitric oxide synthase (nNOS) at the cell membrane in neurons (Eugenin et al. 2007). By a mechanism not fully understood this complex can cause apoptosis in both NMDA receptor positive and negative neurons.

Although most studies implicate NMDA receptors, some evidence suggests that the toxic effects of the Tat protein are mediated through non-NMDA receptors. In fetal neurons the non-NMDA receptor antagonists kynurenate, CNQX and NBQX significantly decreased Tat-induced cell death while there was no significant effect of MK-801 or AP5 (Nath et al. 1996; Cheng et al. 1998).

Tat has also been reported to cause an increase in expression levels and activity of $\mathrm{xCT}$ in rat primary microglia resulting in increased glutamate release (Gupta et al. 2010). Also, Tat decreases the expression of manganese superoxide dismutase, which could lead to lower capacity for anti-oxidant response in cells and ultimately induce oxidative stress (Flores et al. 1993).

Finally, Tat seems to have synergistic effects on other toxins like glutamate and HIV-1 gp120 causing a significant increase in their neurotoxic potency (Wang et al. 1999; Nath et al. 2000). Brief exposure of hippocampal neurons in neonatal rats to Tat and physiological levels of NMDA caused marked cell loss supporting the idea that locally released Tat could enhance NMDA receptor activation-dependent neurotoxic effects (Wang et al. 1999).

Accessory and regulatory HIV proteins neurotoxicity and glutamate

In addition to gp120 and Tat, other less well studied HIV proteins have been identified and have been shown to contribute to glutamate-related toxicity. These include gp160, gp41 and viral protein R (Vpr) (Hussain et al. 2008; Gorantla et al. 2012). Gp41 facilitates the release of glutamate from glial cells in vitro suggesting that this protein may contribute to the excitotoxic effects of HIV infection (Kort 1998). Gp41 was shown to be more effective than gp120 at releasing glutamate in rat parietal cortical slices (Wang and White 2000). Another study showed that both gp120 and its precursor gp160, can both alter NMDAinduced intracellular free calcium levels leading to neurotoxicity (Lannuzel et al. 1995). Vpr transgenic mice displayed higher levels of glutamate in the cortex and basal ganglia along with lower levels of glutamate transporters, EAAT1 and EAAT2 (Noorbakhsh et al. 2010; Power et al. 2012). These findings correlated to disturbances in both motor and cognitive behaviors (Noorbakhsh et al. 2010).

\section{Regulation of glutamate excitotoxicity in HAND}

Reduction of glutamate receptor signaling

Since the main toxic effects of excess glutamate are thought to be due to excitotoxicity from over activation of glutamate receptors, antagonists of these receptors have been popular therapeutic targets for treatment of HAND (Fig. 2). Early work to ameliorate the effects of excess extracellular glutamate focused on NMDA receptor antagonism, in particular with the use of 1-amino-3, 5-dimethyl-adamantane (memantine) (Lipton 2004). Memantine is an uncompetitive low affinity antagonist of the NMDA receptor that is approved to treat the symptoms of Alzheimer's disease. Memantine can block excessive glutamate activity without interfering with the normal functioning of the receptor (Lipton 2004). Preclinical research mainly focused on the effect of memantine on gp120 induced neuronal damage. Memantine can prevent gp120 toxicity (Lipton 1992b; Muller et al. 1992; Muller et al. 1996) as well as the combined toxicity of gp120 and Tat in neuronal cultures (Nath et al. 2000).

The first in vivo evidence of memantine's neuroprotective effects was established in the gp120 transgenic mice with a significant enhancement of dendritic and presynaptic terminal densities after treatment (Toggas et al. 1996). Impaired synaptic transmission and long-term potentiation (LTP) have been reported in SCID mice injected with human macrophages infected with HIV-1 (Anderson et al. 2004). In this same study, memantine was shown to attenuate these deficits. Based on this preclinical evidence, a 20 -week, randomized, doubleblind, placebo-controlled trial involving HIV-infected participants with mild to severe cognitive impairment was carried out. Memantine showed good tolerability but no improvement in cognitive deficits; a longer follow-up is underway (Schifitto et al. 2007; Zhao et al. 2010).

Other NMDA receptor antagonists such as MK-801, AP-5 and 7-chloro kynurenic acid have also been shown to prevent gp120 induced neurotoxicity in vitro (Lipton et al. 1991; Lipton 1992a, b, c; Corasaniti et al. 1995). In contrast, the non-NMDA receptor antagonist, CNQX failed to show any protection (Lipton et al. 1991; Corasaniti et al. 1995). In a recent study in rat hippocampal neurons, several NMDA receptor antagonists were screened for their effectiveness to prevent Tat-induced cell death and synapse loss. MK-801, memantine and ifenprodil but not the GluN2A-selective NMDA receptor antagonist TCN201 were neuroprotective. Memantine and ifenprodil protected against Tat-induced cell death but had no effect on synapse loss. MK-801 and TCN201 had the opposite effects (Shin et al. 2012). In general, however, the use of glutamate receptor antagonists in patients has been fraught with side effects and few potent glutamate 
receptor antagonists have made it through advanced clinical trials.

Inhibition of enzymes responsible for the formation of glutamate

Given the side effects observed in the clinic while trying to block postsynaptic glutamate receptors directly, one alternative is to try to reduce the presynaptic generation and release of glutamate. In this regard, two enzymes thought to contribute to increased levels of glutamate in the synapse are glutamate carboxypeptidase II (GCPII) and glutaminase. Inhibition of these two enzymes could help abrogate the effects of glutamate excitotoxicity (Fig. 2).

GCPII is a membrane-bound glial enzyme that catalyzes the hydrolysis of N-acetyl-aspartyl-glutamate (NAAG) to $\mathrm{N}$-acetyl aspartate (NAA) and glutamate. NAAG is an abundant peptide neurotransmitter in mammalian brain that is thought to act as an agonist at group II metabotropic glutamate receptors and a mixed agonist at the NMDA receptor (Westbrook et al. 1986; Neale et al. 2000), although some controversy exists regarding these activities (Fricker et al. 2009). GCPII-catalyzed hydrolysis of NAAG is believed to function both to terminate NAAG mediated neurotransmission and to liberate glutamate which then acts at various glutamate receptors. Consequently, GCPII inhibitors could help lower glutamate concentration at the synapse and alleviate glutamate excitotoxicity. This hypothesis has been substantiated by numerous reports where GCPII inhibitors have shown to increase extracellular NAAG and decrease glutamate in the brain measured by microdialysis (Slusher et al. 1999; Nagel et al. 2006) and provide neuroprotective activity in over twenty animal models of disease (Barinka et al. 2012) including inflammatory and neuropathic pain (Chen et al. 2002; Carpenter et al. 2003; Yamamoto et al. 2004), brain ischemia (Slusher et al. 1999), motor neuron disease (Ghadge et al. 2003), spinal cord and traumatic brain injury (Long et al. 2005; Zhong et al. 2005), peripheral neuropathy (Zhang et al. 2006; Carozzi et al. 2009), epilepsy (Witkin et al. 2002) and drug abuse (Peng et al. 2010; $\mathrm{Xi}$ et al. 2010). Further, a GCPII inhibitor, 2-MPPA (2-(3-mercaptopropyl) pentanedioic acid), was used in humans in an exploratory study to assess safety and tolerability of GCPII inhibition. 2-MPPA did not provoke any adverse CNS effects and was well tolerated (van der Post et al. 2005).

The potential therapeutic utility of GCPII inhibition in AIDS-related neurotoxicity was recently evaluated in an in vitro model using rat embryonic hippocampal cultures and gp120IIIB. Gp120IIIB exhibits specificity for CXCR4, the receptor known to induce neuronal apoptosis. 2-PMPA, a potent and selective GCPII inhibitor (Jackson et al. 1996) prevented gp120III-induced apoptosis in a dose-dependent manner. Apoptosis could be resumed in the presence of mGlu3 receptor antagonists or in the presence of antibodies to transforming growth factor (TGF)- $\beta$. The results suggest neuroprotection can be mediated through increases in NAAG and subsequent action at the mGlu3 receptors and TGF- $\beta$ release. Consistent with the localization of GCPII in astrocytic cells, 2-PMPA failed to provide neuroprotection in the absence of glia (Thomas et al. 2009). Evaluation of GCPII inhibitors in animal models of HAND is underway.

Glutaminase catalyzes the hydrolysis of glutamine to glutamate and it is thought to be a major source of glutamate production in the CNS. HIV-1 infected human macrophages and human primary fetal microglia have increased glutaminase mRNA and protein levels (Tian et al. 2008; Erdmann et al. 2009; Huang et al. 2011; Zhao et al. 2012). Macrophages infected with various HIV-1 strains were reported to release high levels of glutamate in the presence of glutamine and this release was inhibited by glutaminase siRNA as well as several structurally diverse glutaminase inhibitors including 6-diazo-5-oxo-L-norleucine (DON), BPTES and its analogs (Zhao et al. 2004; Erdmann et al. 2007). Additional mechanistic studies of glutamate generation in HIV-1 infected macrophages revealed up-regulation of the glutaminase isoform GAC. Glutaminase is normally found in mitochondria but upon infection it is released into cytosol and extracellular space where high levels of glutamine could be rapidly converted to glutamate (Erdmann et al. 2009). Unfortunately, current prototype glutaminase inhibitors are non-specific and reactive (Zhao et al. 2004) or exhibit poor solubility (Wang et al. 2010; Hartwick and Curthoys 2011). Consequently, a meaningful evaluation of the potential of glutaminase inhibition to prevent glutamate excitotoxicity in animal models of neuroAIDS awaits the identification of better drug-like glutaminase inhibitors

\section{Regulation of glutamate transporters}

Oxidative stress in macrophages and microglia is also thought to contribute to increased extracellular glutamate through $\mathrm{xCT}$. Treatment of macrophages and microglial cells with pro-inflammatory factors like lipopolysaccharides (LPS) or HIV-1 Tat protein causes lipid peroxidation due to the ROS that are generated. Cells affected by oxidative stress show alterations in cell signaling, membrane organization, and protein and DNA modification (Niki 2009). In order to neutralize lipid peroxidation, glutathione-Stransferase (GST) catalyzes reactions between reduced glutathione (GSH) and oxidized lipids to form products like 4hydroxynonenal (4-HNE) and acrolein. This detoxification process irreversibly consumes the GSH available in the cell decreasing the anti-oxidant protective power. Replenishment 
of intracellular GSH is thought to occur through $\mathrm{xCT}$ which shuttles cystine (cys2) inside the cell in exchange for glutamate that is released from the cell. Cys2 is the main source of cysteine, required for GSH synthesis. This enhanced cys2 uptake to replenish GSH causes an increase in extracellular glutamate that in turn can contribute to neurotoxicity (Barger et al. 2007). The antiporter also supports a redox cycle over the plasma membrane where cys 2 uptake is followed by intracellular reduction to cysteine and secretion of surplus cysteine into the extracellular space (Banjac et al. 2008; Conrad and Sato 2011). Overall, xCT appears to support an endogenous antioxidant response (through the uptake of cys 2 as well as the release of cysteine) with the concomitant increase of extracellular glutamate. However, the antioxidant response can become neurotoxic when it is activated during inflammation associated with neurodegeneration. When macrophages are stimulated by LPS or TNF $\alpha$, they import cys 2 and release cysteine into the medium resulting in a reduced milieu conducive to $\mathrm{T}$ cell activation; the accumulation of extracellular thiols is inhibited by glutamate suggesting the involvement of $\mathrm{xCT}$ (Angelini et al. 2002). Exposure of cultured primary microglia to HIV Tat causes dose-dependent increases in extracellular glutamate; these increases become higher in the presence of morphine in accordance with the immunomodulatory properties of this opiate agonist. Tat-induced glutamate release was associated with increased expression of the $\mathrm{xCT}$ antiporter and was inhibited by the $\mathrm{xCT}$ prototype inhibitors DLaminoadipic acid and 4-carboxyphenylglycine (Gupta et al. 2010). These findings suggest that Tat-mediated activation of $\mathrm{xCT}$ could be playing a role in HIV-related pathology and that $\mathrm{xCT}$ inhibitors have potential for the treatment of HAND.

HIV-mediated neurotoxicity can also result in inhibition of glutamate transporters GLT1, GLAST, and EAAC1 (Trotti et al. 1996) or in reduction of their expression (Noorbakhsh et al. 2010; Power et al. 2012). Since these transporters are involved in the reuptake of glutamate by the cell after glutamate neurotransmission, inhibition or reduction of expression of these transporters results in aberrant activation of glutamate receptors (Sheldon and Robinson 2007). Consequently, one potential approach is to search for transport activators that could increase either their activity or their expression. This approach has shown promise in other glutamate -related disorders such as ALS (Rothstein et al. 2005). Recent work reports on the identification of pyridazine derivatives that increase the protein levels of the glutamate transporter EAAT2 in astrocytes. (Xing et al. 2011). The effect of these activators in models of neurodegenerative disease including HAND awaits investigation.

\section{Animal models to investigate effects of glutamate regulation in HAND}

In order to investigate if glutamatergic-based therapeutics can be effective in eliminating the symptoms of HAND, one needs an appropriate preclinical animal model. The generation of animal models of HIV has proven to be very challenging owing to the fact that HIV itself is not infectious to rodents. In order to create an accurate animal model for HAND several criteria need to be met. The animal model needs to possess target CNS cells that are permissive to virus infection, have a chronic infection period, display altered blood-brain barrier function to permit transmigration of infected cells and have the ability to maintain viral reservoirs (Gorantla et al. 2012). It would also need to feature the generation of viral proteins such as Tat and gp120 as well as the release of neurotoxic products such as proinflammatory cytokines, chemokines, quinolinic acid, glutamate, arachidonic acid and nitric acid among others. Since the discovery of HIV, several animal models of HAND have been created (Table 1), but like many models of neurodegenerative diseases, no one current model recapitulates the exact characteristics of HAND or HIV-1 associated dementia (HAD) (Gorantla et al. 2012; Jaeger and Nath 2012).

Some of the first and most logical models to be generated were where the full-length HIV-1 DNA was inserted into the mouse genome under the control of various promoters (Santoro et al. 1994; Thomas et al. 1994; Gorantla et al. 2012). A HIV-1 transgenic rat was also developed and cognitive deficits such as impairments in spatial learning as well as evidence of other clinical manifestations of the disease have been reported making it a suitable model for testing therapeutics in rats (Reid et al. 2001; Vigorito et al. 2007; Lashomb et al. 2009). The most commonly used mouse models for HIV are those that express some of the viral proteins generated upon HIV infection such as Tat and gp120 (Toggas et al. 1994; Kim et al. 2003; Gorantla et al. 2012). GFAP-Tat Tg mice possess doxycycline-inducible expression of the Tat protein under control of GFAP promoter while GFAP-HIVgp-120 Tg mice exhibit expression of gp120 protein driven by GFAP promoter that is not inducible (Toggas et al. 1994; Kim et al. 2003; BruceKeller et al. 2008). Spatial learning on the Morris water maze was shown to be impaired in the gp-120 mice (D'Hooge et al. 1999). This is thought to be due to excitotoxic mechanisms as a result of increased NMDA receptor signaling and impaired hippocampal long-term potentiation (LTP) which is believed to be the NMDA receptor-dependent biological correlate of learning and memory (Lipton 1994; Toggas et al. 1996). Indeed, as mentioned previously, the first in vivo evidence of the NMDA receptor antagonist, memantine's neuroprotective 
Table 1 Rodent models of HAND

\begin{tabular}{|c|c|c|}
\hline MODEL & COGNITIVE DEFICITS & REFERENCES \\
\hline $\begin{array}{c}\text { HIV-1 transgenic mouse } \\
\text { full length HIV-1 DNA inserted into mouse genome }\end{array}$ & Not reported & $\begin{array}{l}\text { (Santoro et al, 1994; Thomas et al, 1994; } \\
\text { Gorantla et al, 2012) }\end{array}$ \\
\hline $\begin{array}{l}\text { HIV-1 transgenic rat } \\
\text { insertion of HIV-1 genome }\end{array}$ & Spatial learning deficits in the Morris water maze & $\begin{array}{l}\text { (Vigorito et al, 2007; Lashomb et al., } \\
\text { 2009) }\end{array}$ \\
\hline $\begin{array}{l}\text { gp-120 transgenic mouse } \\
\text { expression of gp-120 driven by GFAP promoter }\end{array}$ & Spatial learning deficits in the Morris water maze & (D'Hooge et al, 1999) \\
\hline $\begin{array}{l}\text { Tat transgenic mouse } \\
\text { doxycycline-inducible expression of the Tat protein driven by GFAP promoter }\end{array}$ & $\begin{array}{l}\text { Memory deficits in Barnes maze, Morris water maze, } \\
\text { novel object recognition and fear conditioning }\end{array}$ & (Carey et al., 2012; Fitting et al, 2012) \\
\hline Intracerebral injection of Tat or gp-120 proteins & $\begin{array}{l}\text { Sensorimotor gating (pre-pulse inhibition) deficits. } \\
\text { Morris water maze, Barnes maze, passive avoidance, fear } \\
\text { conditioning and radial arm maze learning deficits }\end{array}$ & $\begin{array}{l}\text { (Glowa et al, 1992; Pugh et al, 2000; } \\
\text { Sanchez-Alavez et al, 2000; Li et al, } \\
\text { 2004; Fitting et al, 2006; Fernandes et al, } \\
\text { 2007) }\end{array}$ \\
\hline HIV-1 infected HIS/SCID mouse & Not reported & (Jaeger and Nath, 2012) \\
\hline $\begin{array}{l}\text { HIVE mouse } \\
\text { HIS/SCID mice infected with HIV-1 infected monocyte derived macrophages }\end{array}$ & $\begin{array}{l}\text { Spatial learning deficits in the Morris water maze and the } \\
\text { radial arm water maze }\end{array}$ & $\begin{array}{l}\text { (Avgeropoulos et al, 1998; Zink et al, } \\
\text { 2002; Sas et al, 2007) }\end{array}$ \\
\hline $\begin{array}{l}\text { HIV-1 mouse with virus modification } \\
\text { coding region of HIV-1 gp-120 replaced with gp-80 from a rodent-infectious } \\
\text { retrovirus }\end{array}$ & Not reported & (Potash et al., 2005) \\
\hline
\end{tabular}

effects was established in these gp120 transgenic mice (Toggas et al. 1996). Like the gp120 mice, the Tat transgenic mice also exhibit memory deficits as demonstrated by diminished performance in hippocampal-dependent memory tasks such as the Barnes maze, Morris water maze, fear conditioning and novel object recognition (Carey et al. 2012; Fitting et al. 2012). Interestingly, Tat transgenic mice display an increase in expression of the $\mathrm{xCT}$ antiporter which could be the response to increased oxidative stress and excitotoxicity (Bridges et al. 2004). Like gp-120, the Tat protein has been shown to interfere with LTP (Li et al. 2004; Fitting et al. 2012). Since the gp120 and Tat proteins both induce impairments to the glutamate system, these models can be appropriately used to test glutamatergic therapeutics. Direct injection of these proteins into brain areas has also been used to model HAND and have shown cognitive and sensorimotor gating impairments as well as interference in LTP (Glowa et al. 1992; Pugh et al. 2000; Sanchez-Alavez et al. 2000; Li et al. 2004; Fitting et al. 2006; Fernandes et al. 2007). As mentioned above, injection of HIV-1 Tat in mice caused neurotoxicity, seizures, death, neuronal degeneration, astrocytosis and microglia activation (Sabatier et al. 1991; Philippon et al. 1994). Future generation of double or triple transgenic lines combined with the introduction of some neurotoxic products or supernatants from HIV-infected macrophages might be needed to convey the collective effects of the various viral proteins and other HIV-generated toxins in the CNS.

To overcome the fact that HIV does not infect mice, two approaches were undertaken to circumvent the restriction of HIV-1 entry to rodent species. The first approach was on the host side with the generation of various types of humanized mouse models that incorporated a functional human immune system (HIS) into severe combined immunodeficient (SCID) mice and thus permitting HIV infection (Jaeger and Nath 2012). HIV-1 infected monocyte derived macrophages (MDM) were also injected into these SCID mice to create HIV encephalitic (HIVE) mice and many of the pathological features of HIVE as well as cognitive and plasticity deficits were reproduced in these mice which were attenuated with memantine (Tyor et al. 1993; Avgeropoulos et al. 1998; Zink et al. 2002; Anderson et al. 2004; Sas et al. 2007). These mice have been widely used for therapeutic testing but biosafety requirements make them difficult to work with (Gorantla et al. 2012). The other approach to overcome the issue of species recognition was on the side of the virus 
itself. This was accomplished by replacing the coding region of HIV-1 gp120 with that of gp 80 from a rodent-infectious retrovirus called ectotropic murine leukemia virus resulting in the EcoHIV construct (Potash et al. 2005). Cognitive testing has not been carried out in these mice nor have any defects in LTP or the glutamate system been reported to date. These mice have been successfully used for the preclinical evaluation of antiretroviral drugs and vaccines (Hadas et al. 2007; Saini et al. 2007).

All of these models have potential to be used to evaluate new therapeutics but each have their individual pros and cons and none of them encompass the entire HAND symptom repertoire. It is clear that the glutamate system is affected following HIV infection of the CNS and therapeutics aimed at ameliorating these deficits may be beneficial for the symptoms of HAND.

In summary, glutamate excitotoxicity is one of several mechanisms by which HIV exerts neurotoxicity that culminates in HAND. Glutamate is released upon HIV infection of macrophage/microglial cells and has been associated with neurotoxicity mediated by gp120, Tat and other HIV proteins. Several strategies have been used over the years to try to prevent glutamate excitotoxicity, including direct blockade of glutamate receptors. Unfortunately, this approach is fraught with side effects. Another approach has been to inhibit enzymes responsible for the production of glutamate such as glutaminase and GCPII or to regulate the transporters responsible for modulation of extracellular glutamate such as EAAT and xCT. These efforts however, are at an early stage where next steps are dependent on the identification of drug-like inhibitors as well as the development of predictive neuroAIDS animal models.

\begin{abstract}
Acknowledgments The authors thank Dr. Norman Haughey for his comments on the manuscript and to Tim Phelps for the art work. Research is supported by the National Institute of Mental health (NIMH), Center for novel therapeutics for HIV-associated cognitive disorders grant \# 2 P30 MH075673-06. The authors declare that they have no conflict of interest.
\end{abstract}

Open Access This article is distributed under the terms of the Creative Commons Attribution License which permits any use, distribution, and reproduction in any medium, provided the original author(s) and the source are credited.

\section{References}

Anderson ER, Gendelman HE, Xiong H (2004) Memantine protects hippocampal neuronal function in murine human immunodeficiency virus type 1 encephalitis. J Neurosci 24:7194-7198

Angelini G, Gardella S, Ardy M, Ciriolo MR, Filomeni G, Di Trapani G, Clarke F, Sitia R, Rubartelli A (2002) Antigen-presenting dendritic cells provide the reducing extracellular microenvironment required for T lymphocyte activation. Proc Natl Acad Sci U S A 99:1491-1496
Avgeropoulos N, Kelley B, Middaugh L, Arrigo S, Persidsky Y, Gendelman HE, Tyor WR (1998) SCID mice with HIV encephalitis develop behavioral abnormalities. J Acquir Immune Defic Syndr Hum Retrovirol 18:13-20

Bagetta G, Finazzi-Agro A, Palma E, Nistico G (1994) Intracerebral injection of human immunodeficiency virus type 1 coat glycoprotein GP120 does not produce neurodegeneration in rats. Neurosci Lett 176:97-100

Bajetto A, Bonavia R, Barbero S, Schettini G (2002) Characterization of chemokines and their receptors in the central nervous system: physiopathological implications. J Neurochem 82:1311-1329

Banjac A, Perisic T, Sato H, Seiler A, Bannai S, Weiss N, Kolle P, Tschoep K, Issels RD, Daniel PT, Conrad M, Bornkamm GW (2008) The cystine/cysteine cycle: a redox cycle regulating susceptibility versus resistance to cell death. Oncogene 27:16181628

Barger SW, Goodwin ME, Porter MM, Beggs ML (2007) Glutamate release from activated microglia requires the oxidative burst and lipid peroxidation. J Neurochem 101:1205-1213

Barinka C, Rojas C, Slusher B, Pomper M (2012) Glutamate carboxypeptidase II in diagnosis and treatment of neurologic disorders and prostate cancer. Curr Med Chem 19:856-870

Benveniste EN (1998) Cytokine actions in the central nervous system. Cytokine Growth Factor Rev 9:259-275

Brabers NA, Nottet HS (2006) Role of the pro-inflammatory cytokines TNF-alpha and IL-1beta in HIV-associated dementia. Eur J Clin Invest 36:447-458

Brenneman DE, Westbrook GL, Fitzgerald SP, Ennist DL, Elkins KL, Ruff MR, Pert CB (1988) Neuronal cell killing by the envelope protein of HIV and its prevention by vasoactive intestinal peptide. Nature 335:639-642

Bridges CC, Hu H, Miyauchi S, Siddaramappa UN, Ganapathy ME, Ignatowicz L, Maddox DM, Smith SB, Ganapathy V (2004) Induction of cystine-glutamate transporter xc- by human immunodeficiency virus type 1 transactivator protein tat in retinal pigment epithelium. Invest Ophthalmol Vis Sci 45:2906-2914

Bruce-Keller AJ, Turchan-Cholewo J, Smart EJ, Geurin T, Chauhan A, Reid R, Xu R, Nath A, Knapp PE, Hauser KF (2008) Morphine causes rapid increases in glial activation and neuronal injury in the striatum of inducible HIV-1 Tat transgenic mice. Glia 56:1414 1427

Bruzzone S, Verderio C, Schenk U, Fedele E, Zocchi E, Matteoli M, De Flora A (2004) Glutamate-mediated overexpression of CD38 in astrocytes cultured with neurones. J Neurochem 89:264-272

Budka H (1986) Multinucleated giant cells in brain: a hallmark of the acquired immune deficiency syndrome (AIDS). Acta Neuropathol 69:253-258

Budka H (1991) Neuropathology of human immunodeficiency virus infection. Brain Pathol 1:163-175

Carey AN, Sypek EI, Singh HD, Kaufman MJ, McLaughlin JP (2012) Expression of HIV-Tat protein is associated with learning and memory deficits in the mouse. Behav Brain Res 229:48-56

Carozzi VA, Chiorazzi A, Canta A, Lapidus RG, Slusher BS, Wozniak KM, Cavaletti G (2009) Glutamate carboxypeptidase inhibition reduces the severity of chemotherapy-induced peripheral neurotoxicity in rat. Neurotox Res 17:380-391

Carpenter KJ, Sen S, Matthews EA, Flatters SL, Wozniak KM, Slusher BS, Dickenson AH (2003) Effects of GCP-II inhibition on responses of dorsal horn neurones after inflammation and neuropathy: an electrophysiological study in the rat. Neuropeptides 37:298-306

Chandra T, Maier W, Konig HG, Hirzel K, Kogel D, Schuler T, Chandra A, Demirhan I, Laube B (2005) Molecular interactions of the type 1 human immunodeficiency virus transregulatory protein Tat with $\mathrm{N}$-methyl-d-aspartate receptor subunits. Neuroscience 134:145-153 
Checkley MA, Luttge BG, Freed EO (2011) HIV-1 envelope glycoprotein biosynthesis, trafficking, and incorporation. J Mol Biol 410:582-608

Chen IS, Quan SG, Golde DW (1983) Human T-cell leukemia virus type II transforms normal human lymphocytes. Proc Natl Acad Sci U S A 80:7006-7009

Chen SR, Wozniak KM, Slusher BS, Pan HL (2002) Effect of 2(phosphono-methyl)-pentanedioic acid on allodynia and afferent ectopic discharges in a rat model of neuropathic pain. J Pharmacol Exp Ther 300:662-667

Cheng J, Nath A, Knudsen B, Hochman S, Geiger JD, Ma M, Magnuson DS (1998) Neuronal excitatory properties of human immunodeficiency virus type 1 Tat protein. Neuroscience 82:97-106

Cheung R, Ravyn V, Wang L, Ptasznik A, Collman RG (2008) Signaling mechanism of HIV-1 gp120 and virion-induced IL-1beta release in primary human macrophages. J Immunol 180:66756684

Churchill MJ, Wesselingh SL, Cowley D, Pardo CA, McArthur JC, Brew BJ, Gorry PR (2009) Extensive astrocyte infection is prominent in human immunodeficiency virus-associated dementia. Ann Neurol 66:253-258

Coiras M, Lopez-Huertas MR, Perez-Olmeda M, Alcami J (2009) Understanding HIV-1 latency provides clues for the eradication of long-term reservoirs. Nat Rev Microbiol 7:798-812

Conrad M, Sato H (2011) The oxidative stress-inducible cystine/glutamate antiporter, system x (c) (-): cystine supplier and beyond. Amino Acids 42:231-246

Corasaniti MT, Melino G, Navarra M, Garaci E, Finazzi-Agro A, Nistico G (1995) Death of cultured human neuroblastoma cells induced by HIV-1 gp120 is prevented by NMDA receptor antagonists and inhibitors of nitric oxide and cyclooxygenase. Neurodegeneration 4:315-321

Cutler RW, Dudzinski DS (1974) Regional changes in amino acid content in developing rat brain. J Neurochem 23:1005-1009

Debaisieux S, Rayne F, Yezid H, Beaumelle B (2012) The ins and outs of HIV-1 Tat. Traffic 13:355-363

D’Hooge R, Franck F, Mucke L, De Deyn PP (1999) Age-related behavioural deficits in transgenic mice expressing the HIV-1 coat protein gp120. Eur J Neurosci 11:4398-4402

Dickson DW, Lee SC, Mattiace LA, Yen SH, Brosnan C (1993) Microglia and cytokines in neurological disease, with special reference to AIDS and Alzheimer's disease. Glia 7:75-83

Doble A (1999) The role of excitotoxicity in neurodegenerative disease: implications for therapy. Pharmacol Ther 81:163-221

Domercq M, Sanchez-Gomez MV, Sherwin C, Etxebarria E, Fern R, Matute C (2007) System xc- and glutamate transporter inhibition mediates microglial toxicity to oligodendrocytes. J Immunol 178:6549-6556

Dreyer EB, Lipton SA (1995) The coat protein gp120 of HIV-1 inhibits astrocyte uptake of excitatory amino acids via macrophage arachidonic acid. Eur J Neurosci 7:2502-2507

Erdmann N, Zhao J, Lopez AL, Herek S, Curthoys N, Hexum TD, Tsukamoto T, Ferraris D, Zheng J (2007) Glutamate production by HIV-1 infected human macrophage is blocked by the inhibition of glutaminase. J Neurochem 102:539-549

Erdmann N, Tian C, Huang Y, Zhao J, Herek S, Curthoys N, Zheng J (2009) In vitro glutaminase regulation and mechanisms of glutamate generation in HIV-1-infected macrophage. J Neurochem 109:551-561

Eugenin EA, Berman JW (2007) Gap junctions mediate human immunodeficiency virus-bystander killing in astrocytes. J Neurosci 27:12844-12850

Eugenin EA, King JE, Nath A, Calderon TM, Zukin RS, Bennett MV, Berman JW (2007) HIV-tat induces formation of an LRP-PSD95- NMDAR-nNOS complex that promotes apoptosis in neurons and astrocytes. Proc Natl Acad Sci U S A 104:3438-3443
Everall IP, Luthert PJ, Lantos PL (1991) Neuronal loss in the frontal cortex in HIV infection. Lancet 337:1119-1121

Farina C, Aloisi F, Meinl E (2007) Astrocytes are active players in cerebral innate immunity. Trends Immunol 28:138-145

Fernandes SP, Edwards TM, Ng KT, Robinson SR (2007) HIV-1 protein gp120 rapidly impairs memory in chicks by interrupting the glutamate-glutamine cycle. Neurobiol Learn Mem 87:1-8

Ferrarese C, Aliprandi A, Tremolizzo L, Stanzani L, De Micheli A, Dolara A, Frattola L (2001) Increased glutamate in CSF and plasma of patients with HIV dementia. Neurology 57:671-675

Fischer-Smith T, Croul S, Sverstiuk AE, Capini C, L'Heureux D, Regulier EG, Richardson MW, Amini S, Morgello S, Khalili K, Rappaport J (2001) CNS invasion by CD14+/CD16+ peripheral blood-derived monocytes in HIV dementia: perivascular accumulation and reservoir of HIV infection. J Neurovirol 7:528-541

Fitting S, Booze RM, Hasselrot U, Mactutus CF (2006) Intrahippocampal injections of Tat: effects on prepulse inhibition of the auditory startle response in adult male rats. Pharmacol Biochem Behav 84:189-196

Fitting S, Ignatowska-Jankowska BM, Bull C, Skoff RP, Lichtman AH, Wise LE, Fox MA, Su J, Medina AE, Krahe TE, Knapp PE, Guido W, Hauser KF (2012) Synaptic dysfunction in the hippocampus accompanies learning and memory deficits in human immunodeficiency virus type-1 Tat transgenic mice. Biol Psychiatry. doi:10.1016/j.biopsych.2012.09.026 [Epub ahead of print]

Flores SC, Marecki JC, Harper KP, Bose SK, Nelson SK, McCord JM (1993) Tat protein of human immunodeficiency virus type 1 represses expression of manganese superoxide dismutase in HeLa cells. Proc Natl Acad Sci U S A 90:7632-7636

Fonnum F (1984) Glutamate: a neurotransmitter in mammalian brain. J Neurochem 42:1-11

Fricker AC, Mok MH, de la Flor R, Shah AJ, Woolley M, Dawson LA, Kew JN (2009) Effects of N-acetylaspartylglutamate (NAAG) at group II mGluRs and NMDAR. Neuropharmacology 56:1060-1067

Gao HM, Hong JS (2008) Why neurodegenerative diseases are progressive: uncontrolled inflammation drives disease progression. Trends Immunol 29:357-365

Gendelman HE (2012) The neurology of AIDS. Oxford University Press, Oxford

Ghadge GD, Slusher BS, Bodner A, Canto MD, Wozniak K, Thomas AG, Rojas C, Tsukamoto T, Majer P, Miller RJ, Monti AL, Roos RP (2003) Glutamate carboxypeptidase II inhibition protects motor neurons from death in familial amyotrophic lateral sclerosis models. Proc Natl Acad Sci U S A 100:9554-9559

Glowa JR, Panlilio LV, Brenneman DE, Gozes I, Fridkin M, Hill JM (1992) Learning impairment following intracerebral administration of the HIV envelope protein gp120 or a VIP antagonist. Brain Res 570:49-53

Gorantla S, Poluektova L, Gendelman HE (2012) Rodent models for HIVassociated neurocognitive disorders. Trends Neurosci 35:197-208

Gupta S, Knight AG, Knapp PE, Hauser KF, Keller JN, Bruce-Keller AJ (2010) HIV-Tat elicits microglial glutamate release: role of NAPDH oxidase and the cystine-glutamate antiporter. Neurosci Lett 485:233-236

Hadas E, Borjabad A, Chao W, Saini M, Ichiyama K, Potash MJ, Volsky DJ (2007) Testing antiretroviral drug efficacy in conventional mice infected with chimeric HIV-1. AIDS 21:905-909

Hartwick EW, Curthoys NP (2011) BPTES inhibition of hGA(124551), a truncated form of human kidney-type glutaminase. J Enzyme Inhib Med Chem

Haughey NJ, Holden CP, Nath A, Geiger JD (1999) Involvement of inositol 1,4,5-trisphosphate-regulated stores of intracellular calcium in calcium dysregulation and neuron cell death caused by HIV-1 protein tat. J Neurochem 73:1363-1374

Haughey NJ, Nath A, Mattson MP, Slevin JT, Geiger JD (2001) HIV-1 Tat through phosphorylation of NMDA receptors potentiates glutamate excitotoxicity. J Neurochem 78:457-467 
Hill JM, Mervis RF, Avidor R, Moody TW, Brenneman DE (1993) HIV envelope protein-induced neuronal damage and retardation of behavioral development in rat neonates. Brain Res 603:222-233

Holden CP, Haughey NJ, Nath A, Geiger JD (1999) Role of Na+/H+ exchangers, excitatory amino acid receptors and voltage-operated $\mathrm{Ca} 2+$ channels in human immunodeficiency virus type $1 \mathrm{gp} 120$ mediated increases in intracellular $\mathrm{Ca} 2+$ in human neurons and astrocytes. Neuroscience 91:1369-1378

Huang Y, Zhao L, Jia B, Wu L, Li Y, Curthoys N, Zheng JC (2011) Glutaminase dysregulation in HIV-1-infected human microglia mediates neurotoxicity: relevant to HIV-1-associated neurocognitive disorders. J Neurosci 31:15195-15204

Hussain A, Wesley C, Khalid M, Chaudhry A, Jameel S (2008) Human immunodeficiency virus type $1 \mathrm{Vpu}$ protein interacts with CD74 and modulates major histocompatibility complex class II presentation. J Virol 82:893-902

Jackson PF, Cole DC, Slusher BS, Stetz SL, Ross LE, Donzanti BA, Trainor DA (1996) Design, synthesis, and biological activity of a potent inhibitor of the neuropeptidase $\mathrm{N}$-acetylated alpha-linked acidic dipeptidase. J Med Chem 39:619-622

Jaeger LB, Nath A (2012) Modeling HIV-associated neurocognitive disorders in mice: new approaches in the changing face of HIV neuropathogenesis. Dis Model Mech 5:313-322

John GR, Lee SC, Brosnan CF (2003) Cytokines: powerful regulators of glial cell activation. Neuroscientist 9:10-22

Kaul M (2008) HIV's double strike at the brain: neuronal toxicity and compromised neurogenesis. Front Biosci 13:2484-2494

Kaul M, Garden GA, Lipton SA (2001) Pathways to neuronal injury and apoptosis in HIV-associated dementia. Nature 410:988-994

Kim BO, Liu Y, Ruan Y, Xu ZC, Schantz L, He JJ (2003) Neuropathologies in transgenic mice expressing human immunodeficiency virus type 1 Tat protein under the regulation of the astrocytespecific glial fibrillary acidic protein promoter and doxycycline. Am J Pathol 162:1693-1707

Klatzmann D, Barre-Sinoussi F, Nugeyre MT, Danquet C, Vilmer E, Griscelli C, Brun-Veziret F, Rouzioux C, Gluckman JC, Chermann JC et al (1984a) Selective tropism of lymphadenopathy associated virus (LAV) for helper-inducer T lymphocytes. Science 225:59-63

Klatzmann D, Champagne E, Chamaret S, Gruest J, Guetard D, Hercend T, Gluckman JC, Montagnier L (1984b) T-lymphocyte T4 molecule behaves as the receptor for human retrovirus LAV. Nature 312:767-768

Koenig RE, Gautier T, Levy JA (1986) Unusual intrafamilial transmission of human immunodeficiency virus. Lancet 2:627

Kort JJ (1998) Impairment of excitatory amino acid transport in astroglial cells infected with the human immunodeficiency virus type 1. AIDS Res Hum Retroviruses 14:1329-1339

Kreutzberg GW (1996) Microglia: a sensor for pathological events in the CNS. Trends Neurosci 19:312-318

Kure K, Lyman WD, Weidenheim KM, Dickson DW (1990) Cellular localization of an HIV-1 antigen in subacute AIDS encephalitis using an improved double-labeling immunohistochemical method. Am J Pathol 136:1085-1092

Lannuzel A, Lledo PM, Lamghitnia HO, Vincent JD, Tardieu M (1995) HIV-1 envelope proteins gp120 and gp160 potentiate NMDAinduced $[\mathrm{Ca} 2+] \mathrm{i}$ increase, alter $[\mathrm{Ca} 2+] \mathrm{i}$ homeostasis and induce neurotoxicity in human embryonic neurons. Eur J Neurosci 7:2285-2293

Lashomb AL, Vigorito M, Chang SL (2009) Further characterization of the spatial learning deficit in the human immunodeficiency virus-1 transgenic rat. J Neurovirol 15:14-24

Lee C, Tomkowicz B, Freedman BD, Collman RG (2005) HIV-1 gp120-induced TNF- $\{$ alpha $\}$ production by primary human macrophages is mediated by phosphatidylinositol-3 (PI-3) kinase and mitogen-activated protein (MAP) kinase pathways. J Leukoc Biol 78:1016-1023
Lewin SR, Murray JM, Solomon A, Wightman F, Cameron PU, Purcell DJ, Zaunders JJ, Grey P, Bloch M, Smith D, Cooper DA, Kelleher AD (2008) Virologic determinants of success after structured treatment interruptions of antiretrovirals in acute HIV-1 infection. J Acquir Immune Defic Syndr 47:140-147

Li ST, Matsushita M, Moriwaki A, Saheki Y, Lu YF, Tomizawa K, Wu HY, Terada H, Matsui H (2004) HIV-1 Tat inhibits long-term potentiation and attenuates spatial learning [corrected]. Ann Neurol 55:362-371

Lipton SA (1992a) 7-Chlorokynurenate ameliorates neuronal injury mediated by HIV envelope protein gp120 in rodent retinal cultures. Eur J Neurosci 4:1411-1415

Lipton SA (1992b) Memantine prevents HIV coat protein-induced neuronal injury in vitro. Neurology 42:1403-1405

Lipton SA (1992c) Requirement for macrophages in neuronal injury induced by HIV envelope protein gp120. Neuroreport 3:913-915

Lipton SA (1994) HIV-related neuronal injury. Potential therapeutic intervention with calcium channel antagonists and NMDA antagonists. Mol Neurobiol 8:181-196

Lipton SA (2004) Failures and successes of NMDA receptor antagonists: molecular basis for the use of open-channel blockers like memantine in the treatment of acute and chronic neurologic insults. NeuroRx 1:101-110

Lipton SA, Sucher NJ, Kaiser PK, Dreyer EB (1991) Synergistic effects of HIV coat protein and NMDA receptor-mediated neurotoxicity. Neuron 7:111-118

Liu B, Hong JS (2003) Role of microglia in inflammation-mediated neurodegenerative diseases: mechanisms and strategies for therapeutic intervention. J Pharmacol Exp Ther 304:1-7

Liu YP, Yang CS, Chen MC, Sun SH, Tzeng SF (2010) Ca(2+)-dependent reduction of glutamate aspartate transporter GLAST expression in astrocytes by $\mathrm{P} 2 \mathrm{X}(7)$ receptor-mediated phosphoinositide 3kinase signaling. J Neurochem 113:213-227

Long JB, Yourick DL, Slusher BS, Robinson MB, Meyerhoff JL (2005) Inhibition of glutamate carboxypeptidase II (NAALADase) protects against dynorphin A-induced ischemic spinal cord injury in rats. Eur J Pharmacol 508:115-122

Masliah E, Achim CL, Ge N, DeTeresa R, Terry RD, Wiley CA (1992) Spectrum of human immunodeficiency virus-associated neocortical damage. Ann Neurol 32:321-329

Muller WE, Schroder HC, Ushijima H, Dapper J, Bormann J (1992) gp120 of HIV-1 induces apoptosis in rat cortical cell cultures: prevention by memantine. Eur J Pharmacol 226:209-214

Muller WE, Pergande G, Ushijima H, Schleger C, Kelve M, Perovic S (1996) Neurotoxicity in rat cortical cells caused by N-methyl-Daspartate (NMDA) and gp120 of HIV-1: induction and pharmacological intervention. Prog Mol Subcell Biol 16:44-57

Nagel J, Belozertseva I, Greco S, Kashkin V, Malyshkin A, Jirgensons A, Shekunova E, Eilbacher B, Bespalov A, Danysz W (2006) Effects of NAAG peptidase inhibitor 2-PMPA in model chronic pain - relation to brain concentration. Neuropharmacology 51:1163-1171

Nath A, Psooy K, Martin C, Knudsen B, Magnuson DS, Haughey N, Geiger JD (1996) Identification of a human immunodeficiency virus type 1 Tat epitope that is neuroexcitatory and neurotoxic. J Virol 70:1475-1480

Nath A, Haughey NJ, Jones M, Anderson C, Bell JE, Geiger JD (2000) Synergistic neurotoxicity by human immunodeficiency virus proteins Tat and gp120: protection by memantine. Ann Neurol 47:186-194

Neale JH, Bzdega T, Wroblewska B (2000) N-Acetylaspartylglutamate: the most abundant peptide neurotransmitter in the mammalian central nervous system. J Neurochem 75:443-452

Nedergaard M, Takano T, Hansen AJ (2002) Beyond the role of glutamate as a neurotransmitter. Nat Rev Neurosci 3:748-755 
New DR, Maggirwar SB, Epstein LG, Dewhurst S, Gelbard HA (1998) HIV-1 Tat induces neuronal death via tumor necrosis factor-alpha and activation of non-N-methyl-D-aspartate receptors by a NFkappaB-independent mechanism. J Biol Chem 273:1785217858

Niki E (2009) Lipid peroxidation: physiological levels and dual biological effects. Free Radic Biol Med 47:469-484

Noorbakhsh F, Ramachandran R, Barsby N, Ellestad KK, LeBlanc A, Dickie P, Baker G, Hollenberg MD, Cohen EA, Power C (2010) MicroRNA profiling reveals new aspects of HIV neurodegeneration: caspase-6 regulates astrocyte survival. FASEB J 24:1799-1812

Pang Y, Campbell L, Zheng B, Fan L, Cai Z, Rhodes P (2010) Lipopolysaccharide-activated microglia induce death of oligodendrocyte progenitor cells and impede their development. Neuroscience 166:464-475

Peluso R, Haase A, Stowring L, Edwards M, Ventura P (1985) A Trojan Horse mechanism for the spread of visna virus in monocytes. Virology 147:231-236

Peng XQ, Li J, Gardner EL, Ashby CR Jr, Thomas A, Wozniak K, Slusher BS, Xi ZX (2010) Oral administration of the NAALADase inhibitor GPI-5693 attenuates cocaine-induced reinstatement of drug-seeking behavior in rats. Eur J Pharmacol 627:156-161

Philippon V, Vellutini C, Gambarelli D, Harkiss G, Arbuthnott G, Metzger D, Roubin R, Filippi P (1994) The basic domain of the lentiviral Tat protein is responsible for damages in mouse brain: involvement of cytokines. Virology 205:519-529

Popovic M, Lange-Wantzin G, Sarin PS, Mann D, Gallo RC (1983) Transformation of human umbilical cord blood $\mathrm{T}$ cells by human T-cell leukemia/lymphoma virus. Proc Natl Acad Sci U S A 80:5402-5406

Potash MJ, Chao W, Bentsman G, Paris N, Saini M, Nitkiewicz J, Belem P, Sharer L, Brooks AI, Volsky DJ (2005) A mouse model for study of systemic HIV-1 infection, antiviral immune responses, and neuroinvasiveness. Proc Natl Acad Sci U S A 102:3760-3765

Power C, Johnson RT (1995) HIV-1 associated dementia: clinical features and pathogenesis. Can J Neurol Sci 22:92-100

Power C, Hui E, Vivithanaporn P, Acharjee S, Polyak M (2012) Delineating HIV-associated neurocognitive disorders using transgenic models: the neuropathogenic actions of Vpr. J Neuroimmune Pharmacol 7:319-331

Pugh CR, Johnson JD, Martin D, Rudy JW, Maier SF, Watkins LR (2000) Human immunodeficiency virus-1 coat protein gp120 impairs contextual fear conditioning: a potential role in AIDS related learning and memory impairments. Brain Res 861:8-15

Ransohoff RM, Perry VH (2009) Microglial physiology: unique stimuli, specialized responses. Annu Rev Immunol 27:119-145

Reid W, Sadowska M, Denaro F, Rao S, Foulke J Jr, Hayes N, Jones O, Doodnauth D, Davis H, Sill A, O'Driscoll P, Huso D, Fouts T, Lewis G, Hill M, Kamin-Lewis R, Wei C, Ray P, Gallo RC, Reitz M, Bryant J (2001) An HIV-1 transgenic rat that develops HIV-related pathology and immunologic dysfunction. Proc Natl Acad Sci U S A 98:9271-9276

Rothstein JD, Patel S, Regan MR, Haenggeli C, Huang YH, Bergles DE, Jin L, Dykes Hoberg M, Vidensky S, Chung DS, Toan SV, Bruijn LI, Su ZZ, Gupta P, Fisher PB (2005) Beta-lactam antibiotics offer neuroprotection by increasing glutamate transporter expression. Nature 433:73-77

Sabatier JM, Vives E, Mabrouk K, Benjouad A, Rochat H, Duval A, Hue B, Bahraoui E (1991) Evidence for neurotoxic activity of tat from human immunodeficiency virus type 1. J Virol 65:961-967

Sabri F, Titanji K, De Milito A, Chiodi F (2003) Astrocyte activation and apoptosis: their roles in the neuropathology of HIV infection. Brain Pathol 13:84-94

Saini M, Hadas E, Volsky DJ, Potash MJ (2007) Vaccine-induced protection from infection of mice by chimeric human immunodeficiency virus type 1, EcoHIV/NL4-3. Vaccine 25:8660-8663
Sanchez-Alavez M, Criado J, Gomez-Chavarin M, Jimenez-Anguiano A, Navarro L, Diaz-Ruiz O, Galicia O, Sanchez-Narvaez F, Murillo-Rodriguez E, Henriksen SJ, Elder JH, Prospero-Garcia O (2000) HIV- and FIV-derived gp120 alter spatial memory, LTP, and sleep in rats. Neurobiol Dis 7:384-394

Santoro TJ, Bryant JL, Pellicoro J, Klotman ME, Kopp JB, Bruggeman LA, Franks RR, Notkins AL, Klotman PE (1994) Growth failure and AIDS-like cachexia syndrome in HIV-1 transgenic mice. Virology 201:147-151

Sas AR, Bimonte-Nelson HA, Tyor WR (2007) Cognitive dysfunction in HIV encephalitic SCID mice correlates with levels of Interferon-alpha in the brain. AIDS 21:2151-2159

Savio T, Levi G (1993) Neurotoxicity of HIV coat protein gp120, NMDA receptors, and protein kinase C: a study with rat cerebellar granule cell cultures. J Neurosci Res 34:265-272

Schifitto G, Navia BA, Yiannoutsos CT, Marra CM, Chang L, Ernst T, Jarvik JG, Miller EN, Singer EJ, Ellis RJ, Kolson DL, Simpson D, Nath A, Berger J, Shriver SL, Millar LL, Colquhoun D, Lenkinski R, Gonzalez RG, Lipton SA (2007) Memantine and HIV-associated cognitive impairment: a neuropsychological and proton magnetic resonance spectroscopy study. AIDS 21:1877-1886

Sheldon AL, Robinson MB (2007) The role of glutamate transporters in neurodegenerative diseases and potential opportunities for intervention. Neurochem Int 51:333-355

Shin AH, Kim HJ, Thayer SA (2012) Subtype selective NMDA receptor antagonists induce recovery of synapses lost following exposure to HIV-1 Tat. Br J Pharmacol 166:1002-1017

Sindou P, Couratier P, Esclaire F, Yardin C, Bousseau A, Hugon J (1994) Prevention of HIV coat protein (gp120) toxicity in cortical cell cultures by riluzole. J Neurol Sci 126:133-137

Slusher BS, Vornov JJ, Thomas AG, Hurn PD, Harukuni I, Bhardwaj A, Traystman RJ, Robinson MB, Britton P, Lu XC, Tortella FC, Wozniak KM, Yudkoff M, Potter BM, Jackson PF (1999) Selective inhibition of NAALADase, which converts NAAG to glutamate, reduces ischemic brain injury. Nat Med 5:1396-1402

Tan IL, McArthur JC (2012) HIV-associated neurological disorders: a guide to pharmacotherapy. CNS Drugs 26:123-134

Thomas FP, Chalk C, Lalonde R, Robitaille Y, Jolicoeur P (1994) Expression of human immunodeficiency virus type 1 in the nervous system of transgenic mice leads to neurological disease. $\mathrm{J}$ Virol 68:7099-7107

Thomas AG, Bodner A, Ghadge G, Roos RP, Slusher BS (2009) GCP II inhibition rescues neurons from gp120IIIB-induced neurotoxicity. J Neurovirol 15:449-457

Tian C, Erdmann N, Zhao J, Cao Z, Peng H, Zheng J (2008) HIVinfected macrophages mediate neuronal apoptosis through mitochondrial glutaminase. J Neurochem 105:994-1005

Toggas SM, Masliah E, Rockenstein EM, Rall GF, Abraham CR, Mucke L (1994) Central nervous system damage produced by expression of the HIV-1 coat protein gp120 in transgenic mice. Nature 367:188-193

Toggas SM, Masliah E, Mucke L (1996) Prevention of HIV-1 gp120induced neuronal damage in the central nervous system of transgenic mice by the NMDA receptor antagonist memantine. Brain Res 706:303-307

Trotti D, Rossi D, Gjesdal O, Levy LM, Racagni G, Danbolt NC, Volterra A (1996) Peroxynitrite inhibits glutamate transporter subtypes. J Biol Chem 271:5976-5979

Tyor WR, Power C, Gendelman HE, Markham RB (1993) A model of human immunodeficiency virus encephalitis in scid mice. Proc Natl Acad Sci U S A 90:8658-8662

van der Post JP, de Visser SJ, de Kam ML, Woelfler M, Hilt DC, Vornov J, Burak ES, Bortey E, Slusher BS, Limsakun T, Cohen AF, van Gerven JM (2005) The central nervous system effects, 
pharmacokinetics and safety of the NAALADase-inhibitor GPI 5693. Br J Clin Pharmacol 60:128-136

Verderio C, Matteoli M (2001) ATP mediates calcium signaling between astrocytes and microglial cells: modulation by IFN-gamma. J Immunol 166:6383-6391

Verderio C, Bruzzone S, Zocchi E, Fedele E, Schenk U, De Flora A, Matteoli M (2001) Evidence of a role for cyclic ADP-ribose in calcium signalling and neurotransmitter release in cultured astrocytes. J Neurochem 78:646-657

Vigorito M, LaShomb AL, Chang SL (2007) Spatial learning and memory in HIV-1 transgenic rats. J Neuroimmune Pharmacol 2:319-328

Wang YS, White TD (2000) The HIV glycoproteins gp41 and gp120 cause rapid excitation in rat cortical slices. Neurosci Lett 291:1316

Wang P, Barks JD, Silverstein FS (1999) Tat, a human immunodeficiency virus-1-derived protein, augments excitotoxic hippocampal injury in neonatal rats. Neuroscience 88:585-597

Wang Z, Trillo-Pazos G, Kim SY, Canki M, Morgello S, Sharer LR, Gelbard HA, Su ZZ, Kang DC, Brooks AI, Fisher PB, Volsky DJ (2004) Effects of human immunodeficiency virus type 1 on astrocyte gene expression and function: potential role in neuropathogenesis. J Neurovirol 10(Suppl 1):25-32

Wang JB, Erickson JW, Fuji R, Ramachandran S, Gao P, Dinavahi R, Wilson KF, Ambrosio AL, Dias SM, Dang CV, Cerione RA (2010) Targeting mitochondrial glutaminase activity inhibits oncogenic transformation. Cancer Cell 18:207-219

Westbrook GL, Mayer ML, Namboodiri MA, Neale JH (1986) High concentrations of $\mathrm{N}$-acetylaspartylglutamate (NAAG) selectively activate NMDA receptors on mouse spinal cord neurons in cell culture. J Neurosci 6:3385-3392

Witkin JM, Gasior M, Schad C, Zapata A, Shippenberg T, Hartman T, Slusher BS (2002) NAALADase (GCP II) inhibition prevents cocaine-kindled seizures. Neuropharmacology 43:348-356

Wong EH, Kemp JA, Priestley T, Knight AR, Woodruff GN, Iversen LL (1986) The anticonvulsant MK-801 is a potent N-methyl-Daspartate antagonist. Proc Natl Acad Sci U S A 83:7104-7108

Wu P, Price P, Du B, Hatch WC, Terwilliger EF (1996) Direct cytotoxicity of HIV-1 envelope protein gp120 on human NT neurons. Neuroreport 7:1045-1049

Xi ZX, Li X, Peng XQ, Li J, Chun L, Gardner EL, Thomas AG, Slusher BS, Ashby CR Jr (2010) Inhibition of NAALADase by
2-PMPA attenuates cocaine-induced relapse in rats: a NAAGmGluR2/3-mediated mechanism. J Neurochem 112:564-576

Xiao H, Neuveut C, Tiffany HL, Benkirane M, Rich EA, Murphy PM, Jeang KT (2000) Selective CXCR4 antagonism by Tat: implications for in vivo expansion of coreceptor use by HIV-1. Proc Natl Acad Sci U S A 97:11466-11471

Xing X, Chang LC, Kong Q, Colton CK, Lai L, Glicksman MA, Lin CL, Cuny GD (2011) Structure-activity relationship study of pyridazine derivatives as glutamate transporter EAAT2 activators. Bioorg Med Chem Lett 21:5774-5777

Yamamoto T, Hirasawa S, Wroblewska B, Grajkowska E, Zhou J, Kozikowski A, Wroblewski J, Neale JH (2004) Antinociceptive effects of $\mathrm{N}$-acetylaspartylglutamate (NAAG) peptidase inhibitors ZJ-11, ZJ-17 and ZJ-43 in the rat formalin test and in the rat neuropathic pain model. Eur J Neurosci 20:483-494

Zhang W, Murakawa Y, Wozniak KM, Slusher B, Sima AA (2006) The preventive and therapeutic effects of GCPII (NAALADase) inhibition on painful and sensory diabetic neuropathy. J Neurol Sci 247:217-223

Zhao J, Lopez AL, Erichsen D, Herek S, Cotter RL, Curthoys NP, Zheng J (2004) Mitochondrial glutaminase enhances extracellular glutamate production in HIV-1-infected macrophages: linkage to HIV-1 associated dementia. J Neurochem 88:169-180

Zhao Y, Navia BA, Marra CM, Singer EJ, Chang L, Berger J, Ellis RJ, Kolson DL, Simpson D, Miller EN, Lipton SA, Evans SR, Schifitto G (2010) Memantine for AIDS dementia complex: open-label report of ACTG 301. HIV Clin Trials 11:59-67

Zhao L, Huang Y, Tian C, Taylor L, Curthoys N, Wang Y, Vernon H, Zheng J (2012) Interferon-alpha regulates glutaminase 1 promoter through STAT1 phosphorylation: relevance to HIV-1 associated neurocognitive disorders. PLoS One 7:e32995

Zhong C, Zhao X, Sarva J, Kozikowski A, Neale JH, Lyeth BG (2005) NAAG peptidase inhibitor reduces acute neuronal degeneration and astrocyte damage following lateral fluid percussion TBI in rats. J Neurotrauma 22:266-276

Zindler E, Zipp F (2010) Neuronal injury in chronic CNS inflammation. Best Pract Res Clin Anaesthesiol 24:551-562

Zink WE, Anderson E, Boyle J, Hock L, Rodriguez-Sierra J, Xiong H, Gendelman HE, Persidsky Y (2002) Impaired spatial cognition and synaptic potentiation in a murine model of human immunodeficiency virus type 1 encephalitis. J Neurosci 22:2096-2105 